University of Michigan Law School

University of Michigan Law School Scholarship Repository

Articles

Faculty Scholarship

1883

\title{
The Remedies for the Collection of Judgments Against Debtors who are Residents or Property Holders in Another State, or Within the British Dominions
}

Thomas M. Cooley

University of Michigan Law School

Available at: https://repository.law.umich.edu/articles/792

Follow this and additional works at: https://repository.law.umich.edu/articles

Part of the Courts Commons, Jurisdiction Commons, Legal Remedies Commons, and the State and Local Government Law Commons

\section{Recommended Citation}

Cooley, Thomas M. "The Remedies for the Collection of Judgments Against Debtors who are Residents or Property Holders in Another State, or Within the British Dominions." Am. L. Reg. 31 (1883): 697-711.

This Article is brought to you for free and open access by the Faculty Scholarship at University of Michigan Law School Scholarship Repository. It has been accepted for inclusion in Articles by an authorized administrator of University of Michigan Law School Scholarship Repository. For more information, please contact mlaw.repository@umich.edu. 


\section{THE}

\section{AMERICAN LAW REGISTER.}

NOVEMBER 1883.

THE REMEDIES FOR THE COLLECTION OF JUDGMENTS AGAINST DEBTORS WHO ARE RESIDENTS OR PROPERTY HOLDERS IN ANOTHER STATE, OR WITHIN THE BRITISH DOMINIONS.

WHEAEVER a party who has obtained a judgment in one state or county has occasion to take proceedings for its enforcement in another, he finds-perhaps to his surprise-that his judgment as such has no extra-territorial force, but that in other jurisdictions it is merely evidence of a settled demand, upon which judgment must be obtained in a new suit before there can be process for its enforcement. A creditor cannot, for example, upon a judgment recovered in New York, have an execution in Pennsylvaria; for courts issue executions only upon their own judgments; and while it would no doubt be within the competency of legislative power to authorize courts to issue final process upon the transcripts of judgments produced to them from other jurisdictions, it has not, either in the United States or in Great Britain, been deemed wise to do so. By international law judgments properly obtained are entitled to respect everywhere; but when relief is to be given upon them it must be given according to the local law and the local judicial practice; and this involves the necessity of obtaining judgment in the jurisdiction where process of enforcement is desired: McLure v. Benceni, 2 Ired. Eq. 513 ; s. c. 40 Am. Dec. 437 ; Savings Inst. v.Guber, 34 N. J. Eq. 130.

The fact of this necessity is always an embarrassment, and sometimes a very serious one. It may, indeed, in some cases prove

Vor. $\mathrm{XXX1.-88}$ 
an insurmountable obstacle to any remedy whatever, outside the jurisdiction in which the judgment was rendered. Reason for this will generally be found in the nature of the judgment, and its dependence upon some condition or upon the local law where it was given. A judgment may be for the payment of money simply; or it may be for payment subject to conditions, or it may be for the performance of some personal act, such as the delivery of goods, the transfer of corporate stocks, or the conveyance of land, or it may simply affirm the title to property to be in one or the other of the parties. If it be a judgment for the payment of money simply, it will be received elsewhere as evidence of a debt, and judgment may be obtained upon it. But where a judgment is for payment on conditions, the conditions usually arise from something peculiar in the local law, and are likely to depend altogether upon it. But the local law cannot be taken with the judgment into another state. If a court bas decreed the performance of some personal act, and the party has failed to obey, a court in a foreign state, where he may happen to be, will not undertake to compel obedience. A court in Georgia would not, on the footing of a decree made in Alabama, for the conveyance of Georgia lands, compel one of its citizens to make the transfer. If the transfer were actually made in pursuance of the decree, the transferree might protect himself in the enjoyment of the property under it: Penn v. Lord Baltimore, 1 Ves. 444 ; Massie v. Watts, 6 Cranch 148; Watkins v. Holman, 16 Pet. 25; Corbett v. Nutt, 10 Wall. 464; Wood v. Parsons, 27 Mich. 159; and if without obtaining conveyance he succeeds in acquiring the possession, the decree may, perbaps, be received as an equitable defence to any suit that may be instituted to oust him: Burntey v. Stevenson, 24 Ohio St. 474. But if the plaintiff in such a decree is compelled to invoke judicial aid to obtain in another jurisdiction the relief which the decree undertakes to give him, he may find, perhaps, that he is under the necessity of taking up the litigation anew and proving his case again. He may even find that while the court had ample jurisdiction for some purposes to make the decree the benefit of which he seeks, it had none for the purposes most important to him, and therefore he can take advantage of it only so far as he has suoceeded in enforcing it in the state where it was 'rendered: Wakins v. Holman, 16 Pet. 25 ; Lewis v. Darling, 16 How. 1; Brown v. Easton, 23 Vt. 435; Salmond v. Price, 13 Ohio 368; Price v. Jolnnston, 1 Ohio 
St. 390 ; McLean v. Lafayette Bank, 3 McLean 622 ; MLac Gregor v. MacGregor, 9 Iowa 65 . A judgment in the alternative a foreign court may also decline to enforce. It has been held in Maryland that a judgment rendered in another state for a return of property in a replevin suit, and in default of return, for the value of the property, would not support an action of debt elsewhere: Thorner v. Battory, $41 \mathrm{Md} .593$; s. c. $20 \mathrm{Am}$. Rep. 74 . And in Vermont a like ruling was made respecting a judgment of another state for the penalty of a bond, to be discharged on the payment of a lesser sum in instalments. Such a judgment, it was said, not being for an absolute indebtedness, has no force whatever except in the very jurisdiction where it was rendered and whose statutes alone support it: Dimick v. Brooks, 21 Vt. 569. These cases, though decided upon special facts, have general application. We shall not, however, discuss such cases here, but shall limit our attention to judgments for the simple payment of money, passing by those of exceptional and peculiar character, and also proceedings in rem, which stand upon their own reasons.

A money judgment is evidence of a settled demand, but it is not always conclusive evidence. And when its conclusiveness is in question it may become necessary to distinguish between a judgment rendered in a country foreign to that in which suit is brought upon $i t$, and a judgment rendered in one of the states of the American Union and sued upon in another. In the one case the force and effect of the judgment must depend altogether upon international law; in the other we have, besides the principles of international law, the provision of the Constitution of the United States that "full faith and credit shall be given in each state to the public acts, records and proceedings of every other state. And the Congress may by general laws prescribe the manner in which such acts, records and proceedings shall be proved, and the effect thereof:" Art. 4, sect. 1. This provision, it is generally conceded, adds something to the force and effect which the judgments of other jurisdictions receive from the laws of nations, and precludes certain defences which might otherwise be open. In a certain qualified sense state judgments are made by it domestic judgments in every state: McGilvray v. Avery, 30 Vt. 538.

It will be convenient, therefore, to consider the two classes of judgments separately.

I. As to judgments rendered in one state and sued upon in 
another. The coustitution, as has been seen, declares that full faith and credit shall be given them, and by this it was no doubt meant that they should receive in other states the same faith and credit they are entitled to in the state in which they are rendered, and Congress, pursuant to the power conferred upon it, has so declared: Mills v. Duryee, 7 Cranch 481 ; Hampton v. DIc Connel, 3 Wheat. 234; McElmoyle v. Cohen, 13 Pet. 312. But "faith and credit" is one thing; force and effect is another; and a judgment may be entitled to faith and credit everywhere, and yet outside the state where it was rendered be of no force or effect whatever. Some judgments from their nature must of necessity spend their force within the state; as where they provide for the performance of some local act; others for other reasons may not be enforceable elsewhere. And sometimes, as has been intimated, it may appear, that the jurisdiction of the court rendering it was insufficient for any purpose of affirmative relief elsewhere. And as the question of jurisdiction is always of prime importance, a ferw words in explanation may be essential.

It is an admitted principle in the law of nations, that every state, for the purpose of enforcing private rights and redressing private wrongs, has jurisdiction not only over its own citizens, but also over all others who may, for business -or pleasure, come within its territory. For judicial purposes this jurisdiction is enforced by means of the personal service of process or some substitute therefor, whereby the party is brought into court and is permitted to meet and defend the charges made and the demands set up against him. The service gives the court jurisdiction of his person, and entitles it, if the demands are sustained, to enter a personal judgment against him. But the party sued may waive the service by voluntarily, in person or by attorney, appearing in the suit; and this appearance makes the jurisdiction of the person equally complete and effectual.

It is also an admitted principle that every state has jurisdiction of all property which is within its territory and protected by its laws, whether belonging to its own people or owned abroad; and that it may entertain suits for the purpose of enforcing claims against such property or against its owners. But as it may not be possible for the purposes of suits to obtain service upon the orner, it is necessary, if the jurisdiction of the state in respect to the property is to be enforced, that some substitute for such service be 
provided for. If, for example, a citizen of Indiana owes a debt to a citizen of Michigan, and also is owner of property in Michigan, so that his property but not his person is subject to the laws of the last-mentioned state, it will still be necessary, if the property is to be reached for the satisfaction of the debt, that judgment be first obtained upon it; and no judgment is possible until the party concerned is actually or constructively notified to appear and defend. If the party is not actually within the state it will be impossible to make service of process upon him; for one state can no more send its writs into another state for service than it could send its officers to make arrests or to collect taxes; one of these would be as much an invasion of sovereignty as the others: Bischoff v. Wethered, 9 Wall. 312 ; Pennoyer v. Neff, 95 U. S. 714; Scott v. Noble, 72 Penn. St. 115. The state must, therefore, provide for constructive notice; and what this shall be, and what its force and effect, must be determined by the wisdom of the legislature. Perhaps it will be by attachment of property, and the notification of the owner by mail or in the public papers, or perhaps by notification without attachment. Whatever it may be, if the law on the subject is complied with the court in which suit is brought obtains jurisdiction to proceed to judgment, and upon this judgment the property within the state may be seized and applied in satisfaction.

But while the court in this manner obtains jurisdiction for the purposes of a judgment, and may give such effect to the judgment as shall be prescribed by the laws of the state so far as any property within the state is concerned (St. Clair v. Cox, 106 U. S. 353; Pope v. Terre Haute Car Mfg. Co., 87 N. Y. 137), it acquires no jurisdiction whatever of the person of the defendant, and the judgment charges him with no personal obligation for its satisfaction. If property within the state is sold upon the judgment, the sale will be recognised everywhere as valid: Melhop $\nabla$. Doane, 31 Iowa 397 ; s. c. $7 \mathrm{Am}$. Rep. 147 ; but if the defendant is sued upon the judgment in another state, it will be treated, for all the purposes of a personal demand, as a mere nullity : D'Arcy v. Ketchum, 11 How. 165; Pennoyer v. Neff, 95 U. S. 714; St. Clair v. Cox, 106 Id. 353 ; Ruggles v. Coleman, Hardin 413; Thurber v. Blackbourne, 1 N. H. 242 ; Whittier v. Wendell, 7 Id. 257 ; Sim v: Frank, 25 Ill. 125; Jones v. Warner; 81 Id. 348; Kilburn v. Woodworth, 5 Johns. 41; s. c. 4 Am. Dec. 321; Robinson v. Ward, 8 Johns. 86 ; s. c. 5 Am. Dec. 327 ; Bates v. Delavan, 5 
Paige 299; Starbuck v. Murray, 5 Wend. 148 ; s. c. 21 Am. Dec. 172 ; Bissell v. Briggs, 9 Mass. 462 ; s. c. 6 Am. Dec. 88 ; Pelten v. Platner, 13 Ohio 209 ; s. c. 42 Am. Dec. 197 ; Arndt v. Arndt, 15 Ohio 33 ; Rogers v. Burns, 27 Penn. St. 525 ; Winston v. Taylor, 28 Mo. 82; Outhwite v. Porter, 13 Mich. 533; Rentschler v. Jamison, 6 Mo. App. 135.

It is also sometimes provided by statute that when suit is brought upon a joint obligation, and one or more of the parties are served with process but not all, the case may proceed to judgment against all, and execution may be had in form against all upon the judgment. But whatever may be the force the statute shall assume to give the judgment within the state; it can give it none elsewhere as to the party not served; and it could not in any other state be made the ground of a personal recovery against him. Suich a party has not had his day in court, and a judgment cannot charge him with a personal obligation until that has been accorded him; Wood v. Walkinson, 17 Conn. 500; Bimeler v. Dawson, 5 Ill. 536 ; s. c. 39 Am. Dec. 430 ; Oakley v. Aspinwall, 4 N. Y. 513 ; Frothingham v. Barnes, 9 R. I. 474 ; Seott v. Noble, 72 Penn. St. 115.

But it may sometimes appear that although the party was served with process, the court had no jurisdiction of the case, because it was not such a case as the law of the state had referred to that particular tribunal for hearing and judgment. Such a case is one in which the court has no jurisdiction of the subject-matter; and if it assumes to act, its action and judgment will be entitled to no respect and no obedience, either in its own state or elsewhere. This is so plain a case as to need neither comment nor authorities.

It may be assumed, however, that generally when suit is brought upon a judgment in another state, there will be nothing in the recitals of the transcript to show any want of jurisdiction of either subject-matter or person. In such a case the judgment is entitled to "faith and credit" as establishing conclusively an indebtedness. It will be assumed that the court had jurisdiction; but no such assumption can be made in opposition to the recitals of the record; and if the recitals are that a certain insufficient notice was given, it cannot be presumed there was any other. See Galpin v. Page, 18 Wall. 350 ; Meyer v. Ralli, 1 G. P. Div. 358. Still as it is always possible that the court may have rendered the judgment 
without jurisdiction either of the subject-matter or the person, if the party sued is allowed to show this fact, he will thereby show that the judgment, either generally or as to him at least, is no judgment at all, and therefore entitled to no faith and credit. It has sometimes been thought that the defendant would be allowed to make this showing when he could do so without contradicting the recitals of the record, but not otherwise; the recitals importing absolute verity ; but the later authorities do not sustain this restriction. The defendant according to these may show in any case that the court rendering the judgment had no jurisdiction of the subject-matter; or, if it ever had it, lost it before judgment: Thomp. son v. Whitan, 18 Wall. 457 ; Reel v. Elder, 62 Penn. St. 308; s. c. 1 Am. Rep. 414; Pennywit v. Foote, 27 Ohio St. 600; s. c. $22 \mathrm{Am}$. Rep. 340. He may also show that the court never acquired jurisdiction of his person; and for this purpose may give evidence that the process issued in the case was never served, and if the record shows an appearance entered for him by attorney, he may prove that the appearance was unauthorized : Shelton v. Tiffin, 6 How. 163; Knowles v. Gas Light Co., 19 Wall. 58; Bartlett v. Znight, 1 Mass. 401 ; s. c. 2 Am. Dec. 36 ; Shumway v. Stillman, 4 Cow. 292 ; s. c. 15 Am. Dec. 374; 6 Wend. 447 ; Thompson v. Emmert, 15 Ill. 416 ; Lawrence v. Jarvis, 32 Ml. 304 ; Marx v. Fore, 51 Mo. 69 ; s. c. 11 Am. Rep. 432 ; People v. Dawell, 25 Mich. 247 ; s. c. 12 Am. Rep. 260 ; Eaton v. Hasty, 6 Neb. 419 ; s. c. 29 Am. Rep. 365 ; Carleton v. Bickford, 13 Gray 596; Gilman v. Gilman, 126 Mass. 26 ; s. c. 30 Am. Rep. 646 ; Bowler v. Huston, 30 Grat. 266 ; s. c. 32 Am. Rep. 673 ; Rankin v. Goddard, 54 Me. 28 ; 55 Id. 389.

On the other hand if the court had jurisdiction of the person of the defendant, the fact that the jurisdiction was exercised irregularly, is of no legal importance when suit is brought upon the judgment. Neither is it important that the court erred in matter of law and reached an erroneous conclusion. Errors like these may warrant the judgment being set aside on appeal or writ of error, but they do not authorize it to be attacked otherwise; or, as the legal phrase is, collaterally: Kinnier v. Kinnier, 45 N. I. 535 ; s. c. $6 \mathrm{Am}$. Rep. 132. And there would be an obvious impropriety, to use no stronger term, in the courts of one state assuming to sit as courts of error on the proceedings of courts of other states. 
when their jurisdiction has been ample and they are only charged with error in judgment or in proceeding.

Whether a judgment thus sued upon can be assailed for fraud in obtaining it has been a mooted question, and there are decisions both ways. But as this, under the Constitution of the United States, must be a Federal question, the decisions of the Federal Supreme Court must be conclusive upon it-and these deny the right of the defendant to set up such a defence. If he claims that the judgment was obtained by fraud, he may have the proper remedy in the state where it was rendered: Christmas v. Russell, 5 Wall. 290 ; Maxwell v. Stewart, 22 Id. 77. Probably in some cases relief might be had in equity in the state where the judgment was sued over; but such cases would stand upon peculiar facts. It has been held that a plea that the defendant was fraudulently enticed into the jurisdiction for the purpose of obtaining service of process would not be sustained, it being presumed that the court from which the process issued would set it aside if a fraudulent use of it were shown: Luckenbach. v. Anderson, 47 Penn. St. 123; contra, Dunlap v. Cody, 31 Iowa 260 ; s. c. 7 Am. Rep. 129. See Dobson ₹. Pearce, 12 N. Y. 156.

II. When suit is brought upon a judgment rendered in a foreign country it is generally assumed that the rules of conclusiveness are somewhat different from those applied to state judgments under the federal constitution, though it may not be very easy to point out in what the difference consists. Formerly it was held in England and also in this country that a foreign judgment was only prima facie evidence of indebtedness, and the defendant when sued upon it was at liberty to avail himself of any defences which would have been allowed to him in the original cause: Philips v. Hunter, $2 \mathrm{H}$. Bl. 410 ; Buttrick v. Allen, 8 Mass. 273 ; s. c. 5 Am. Dec. 105 ; Wit. liams v. Preston, 3 J. J. Marsh! 600 ; s. c. 20 Am. Dec. 179 . But as Vattel shows, to assume to inquire into the justice of a definitive sentence is an attack upon the jurisdiction of the sovereign who passed it: Law of Nations, b. 2, ch. 7, sect. 84; see, also, Story Confl. of L., ch. xv ; Whart. Confl. of L., sect. 815; and the later cases all agree that this is wholly inadmissible: De Cosse Brissae v. Rathbone, 6 H. \& N. 301 ; Henderson v. Henderson, 6 Q. B. 298 ; Bank of Australasia v. Harding, 9 C. B. 669 ; Bank of Australasia v. Nias, 16 Q. B. 717 ; Vanquelin v. Bouard, 15 C. B. N. S.:311; Godard v. Gray, I. R., 6 Q. B. 139; Ochsenbein v. 
Papelier, I. R., 8 Ch. App. 695; Doglioni v. Crispin, L. R., 1 H. I. 301; Simpson v. Fogo, 1 J. \& H. 18; 1 H. \& M. 195; Messina v. Petrococchino, L. R., 4 P. C. 144. The ground upon which the authorities proceed is that where a court of competent jurisdiction has adjudicated a certain sum to be due from another, a legal obligation arises to pay that sum; and upon this obligation an action of debt to enforce the judgment may be maintained: Williams v. Jones, 13 M. \& W. 628, 633; Russell v. Smith, 9 Id. 819. It will not be admissible, therefore, to go behind the judgment for the purpose of attacking the justice of the conclusion on the merits; and the fact that any defence which is set up would have been available in the original action is a conclusive answer to it: Vanquelin v. Bouard, 15 O. B. N. S. 341 c. Even the pendency of an appeal from the foreign judgment to a court of review in the same country is no defence if the appeal does not vacate or suspend the judgment: Scott v. Pilkington, 2 Best \& S. 11. But this conclusiveness of the judgment is necessarily based upon the fact of jurisdiction to render it; not a prima facie or apparent jurisdiction merely, but a jurisdiction in fact; and therefore the defendant when the duty is counted upon must be at liberty to disprove it by showing that the fact from which alone the duty can spring was wanting: Schibsby v. Westenholz, L. R., 6 Q. B. 155; Roussillon v. Roussillon, 14 Ch. Div. 351. And whatever can be said in favor of permitting the jurisdiction to be inquired into when the judgment of a sister state is sued upon will apply with additional force in suits upon foreign judgments; for the danger that courts will be imposed upon by a false showing of jurisdiction is increased in proportion to the distance from the court of the party whom it is hoped to bind by its action.

That fraud in obtaining the judgment is a defence to it is settled: Ochsenbein v. Papelier, L. R., 8 Ch. App. 695 . Mr. Justice BLAckBorn said in one case that "Probably the defendant may show that the judgment was obtained by the fraud of the plaintiff, for that would show that the defendant was excused from the performance of the obligation thus obtained:" Godard v. Gray, L. R., 6 Q. B. 139, 149. He might have said it would show that no obligation was ever established. He adds: "It may be that when the foreign court has knowingly and perversely disregarded the rights given to an English subject by English law, that forms a valid excuse for disregarding the obligation thus imposed on him;

VoL. XXXI.-89. 
but we prefer to imitate the caution of the present lord chancellor (In Castrique v. Imrie, I. R., $4 \mathrm{H}$. I. 445), and to leave those questions to be decided when they arise:" Godard v. Gray, supra. This last suggestion is one of immense possibilities; for it is very easy to say, and perhaps to believe, that any unjust judgment rendered abroad was in disregard of the rights given to English subjects by English law; and if we so believe we may easily imagine that the foreign court was perverse in rendering it. Perhaps, however, the learned justice only intended his remark for: cases in which fundamental principles of justice which were of universal acceptance had obviously been disregarded: see Simpson v. Fogo, 1 J. \& H. 18 ; 1 H. \& M. 195; Meyer v. Ralli, 1 C. P. Div. 358; Shaw v. Gould, L. R., 3 H. L. 55 . Lord WestBuRY says, in this last case, that a judgment cannot claim extra-territorial authority unless pronounced in accordance with the rules of international public law ; and there would be general agreement when that appeared that there would be no want of comity or of respect for the sovereign authority in refusing to recognise the judgment. One of these principles is that no man shall be judge in his own cause. If, therefore, it appears that the judge or one of the judges had an interest in the judgment rendered, the courts of other countries ought to treat it as a nullity (Price v. Dewhurst, $8 \mathrm{Sim}$. 279), as the courts of the same country would when their attention was called to the facts: Dimes v. Proprietors, 3 H. L. Cas. 759, 793 ; Hall จ. Thayer, 105 Mass. 219. But the interest in such a case would be a disqualifying fact and would defeat the jurisdiction, so that the case would be within the general principle before stated.

The justice of permitting fraud in obtaining a foreign judgment to be shown seems to be conceded. Still it must be admitted that the value of a foreign judgment is greatly diminished by the liability to have such a defence set up in a country distant from that in which the judgment was rendered and where the proof of the facts may be difficult and perhaps impossible. Especially is this the case now that parties are very generally allowed to be witnesses in their own favor, and if disposed to be dishonest will find means and opportunity to invent a fraudulent showing which the creditor living at a distance will not be prepared to disprove.

The rules of law above laid down are believed to be generally accepted and followed throughout Great Britain and its dominions, as well as the United States. See Waydell v. Insurance Co., 21 
U. C., Q. B. 612 ; Olemacher v. Brown, 44 Id. 366 ; Turcotte v. Dawson, 30 U. C., C. P. 23 . There is or was a statute in the province of Quebec which expressly assumed to give to parties sued upon foreign judgments the benefit of all defences which were open to them in the original suit and which was, therefore, in distinct antagonism to the principle settled by the English cases already referred to. As that principle has been laid down as one of general application, it is hardly to be supposed that any one of the provinces of the empire will insist on ignoring it, if indeed it has the power to do so, of which no one not familiar with the relations of the provinces to the imperial government, and the implied as well as express restrictions upon their authority, ought to venture to express an opinion.

III. Having thus stated the general rules it may be useful to direct attention briefly to the case of corporations, that we may see how far, if at all, the general rules are affected by the fact that the defendant in the judgment is an artificial instead of a natural person.

In general, of course, the application of the rules must be the same. A judgment against a corporation is equally conclusive with one against a natural person, provided full jurisdiction existed to enter it. Neither is there any question that a corporation may disprove jurisdiction as a natural person may. But a corporation being intangible and incapable of acting except by agents, must be brought before the court according to some method specially devised by law for the purpose; and this method will generally have regard to the nature of the case and of the corporation, and to the manner in which the corporate powers are customarily manifested. The common-law method of subjecting a corporation to the jurisdiction of a court was troublesome and expensive, and it has been found desirable to prescribe by statute something more simple. This generally consists of a service of the writ upon some principal officer, who is made the agent of the corporation for the purpose of receiving it. A service made upon a domestic corporation in the manner prescribed by statute, is the equivalent for all purposes of jurisdiction of personal service upon a natural person, and a judgment obtained upon it would be respected accordingly everywhere.

But in modern times a very large share of all the business of the world is done by corporations, which do not limit their operations 
to the state or country to which they owe their corporate powers, but establish offices for the general transaction of business in other states and countries. There is no inherent right to do this; for one state cannot grant corporate powers to be exercised within the limits of another; but the consent of such other state must be obtained or the exercise will be unwarranted. Nevertheless it is not customary to interpose objections, when the corporate business is a proper one, and when there is nothing in it or in the manner of conducting it which is opposed to the public policy or laws of the state. Instead of this the state establishes regulations which contemplate that foreign corporations will carry on business within it; and among these will be provisions for the commencement of suits against such corporations. To these regulations a corporation coming into the state with its business must be deemed to have assented, and by its assent to have submitted itself to the jurisdiction and to the method prescribed by law for enforcing it: Bank of Australasia v. Nias, 16 Q. B. 717 ; Copin v. Adamson, L. R., 9 Exch. 345 ; Libbey v. Hodgdon, 9 N. H. 394. But a state will sumetimes go farther than this, and besides establishing general regulations, will require certain classes of foreign corporations to submit to special conditions, such as that they shall appoint an agent residing within the state who shall be empowered to receive service of process for the corporation. This is a very common provision in the case of foreign insurance companies; and if there was ever any doubt of the right to impose the condition there is none now, for the right has been authoritatively and repeatedly affirmed: Lafayette Ins. Co. v. French, 18 How. 404; Bank of Augusta v. Earle, 13 Pet. 519; Paul v. Virginia, 8 Wall. 168; Ducat v.Chicago, 10 Id. 410 ; 94 Ill. 172; Insurance Co. v. Morse, 20 Wall. 445; 30 Wis. 496 ; Doyle v. Continental Ins. Co., 94 U. S. 535; Tatem v. Wright, 23 N. J. 429; Home Ins. Co. v. Davis, 29 Mich. 238; Hagerman v. Empire Slate Co., 97 Penn. St. 534; Midland, \&c., Ry. Co. v. MIcDermid, 91 Ill. 170; Gibbs v. Queen Ins. Co., 63 N. Y. 114; Pringle v. Woolworth, 90 Id. 502. Services upon the agent so appointed is equivalent to personal service upon an individual, and is sufficient for the purposes of a judgment in personam.

Perhaps it might be competent in these cases to go still further and make the fact of the corporation doing business within a state a personal submission of the corporators themselves to the jurisdic- 
tion, so that a judgment against the corporation should bind them personally. That the state which confers corporate powers may require that non-resident corporators shall personally submit to its jurisdiction has been decided in England in the case of French and Colonial corporations: Vallee v. Dumerque, 4 Exch. 290; Bank of Australasia v. Nias, 16 Q. B. 717 ; Bante of Australasia v. Harding, 9 C.B. 661 ; Copin v. Adamson, L. R., 9 Exch. 345; and what a state might do in granting corporate powers, it would seem, it might do also when consenting to the exercise within its limits of corporate powers which are granted elsewhere.

But the case is altogether different when a foreign corporation abstains from entering the state with its business, for in that case it does not submit itself to the jurisdiction, and the state has no more porrer to subject it to the process of the courts than it has to do the same with an individual who is never within its territory. There may be a qualified jurisdiction even in such a case; for the corporation may have property within the state as a natural person may; and the state may provide for constructive service upon the corporation as a means of reaching it: Pope v. Terre Haute Car Mfg. Co., 87 N. Y. 137; but any judgment taken against it without voluntary appearance would be worthless outside the state except for the purpose of protecting such rights in property as may have been actually acquired under it within the state.

If a state in general terms provides by law the manner in which a foreign corporation may be served with process-as, for example, that the service may be made on its president or secretary-the mere presence within the state of an individual who happens to be one of these offcers, when the corporation itself abstains from bringing its business there, would not in any sense be the presence of the corporation, and a service upon him as the representative of the corporation would be treated in any other jurisdiction as a nullity : St. Clair v. Cox, 106 U. S. 350; Newell v. Great Western Ry. Co., 19 Mich. 336; Moulin v. Trenton Ins. Co., 24 N. J. 222 ; Cumden, \&c., Co. v. Swede Iron Co., 32 Id. 15; Latimer จ. Union Pacific Railroad Co., 43 Mo. 105; Nash v. Evangelical, \&c., Church, 1 Miles (Pa.) 126; Midland, \&c., Ry.Co. v. MoDermid, $91 \mathrm{Ml}$. 170. It might be sufficient within the state to enable corporate property there situated to be reached, but it would be worthless for any other purpose. 
When, therefore, suit is brought upon a foreign judgment against a corporation it is not sufficient that it appears to have been rendered in compliance with the local law. It will be necessary, further, either, 1. That the corporation existed by law within the jurisdiction where the judgment was rendered; or 2. That it expressly submitted itself to the jurisdiction; or 3. That by carrying on its business within the jurisdiction it impliedly assented to the local laws and to the provisions made thereby for the commencement of suits. We say nothing now of the burden of proof-whether it lies upon the plaintiff to show the facts or the defendant to disprove them; but if the transeript of the judgment is to be considered as making out a prima facie case for the plaintiff, the defendant would certainly be at liberty to defeat it by showing that the necessary facts to give jurisdiction were wanting in the case.

IV. It should be stated that there have sometimes been attempts, by express statutory provisions, to give to judgments rendered against non-residents upon constructive notice the force and effect of judgments in personam. There have been such statutes in Fngland and some of its dependencies, and also in France; but attempts to give them extra-territorial force have always been unsuccessful. It has been tersely said in one case that such a statute is an attempt by one country to pass a law to bind the world (Schibsby v. Westenholz, L. R., 6 Q. B. 155), which is simply preposterous. The English courts have frankly admitted that a statute of the imperial parliament to that purport would be very properly disregarded in other countries: Id. And see Rousillon v. Rousillon, $14 \mathrm{Ch}$. Div. 351; and a Canada statute to that effect has been held inoperative in the United States: MLcEwan v. Zimmer, 38 Mich. 765 ; s. c. 31 Am. Rep. 332.

$\nabla$. When a judgment rendered in one state or country and sued over in another is found to have been rendered with proper jurisdiction, so that a new judgment is given upon it, the remedies for the collection of such new judgment will be the same and no other which are given by the court which renders the judgment in other cašes. Every court in enforcing its own judgments administers the law of its own sovereignty and no other.

VI. We have said nothing in this article of the right of a state, when consenting to a foreign corporation coming with its business within the state, to impose the condition that it shall give security for the performanoe of such contracts as it shall enter into with its 
citizens. Insurance companies are sometimes subjected to such conditions, and are required to deposit with some public officer bonds or stocks to secure the payment of losses. That the state may impose such conditions is settled by the decisions of the Federal Supreme Court: Lafayette Ins. Co. v. French, 18 How. 404; Paul v. Virginia, 8 Wall. 168; Ducat v. Chicago, 10 Id. 410. And having received the securities it has ample power to provide for giving remedies to parties for whose protection they are deposited.

THomas M. Cooley. 